Tawny Owl (Strix aluco), of wild Mallards (Anas platyrhyncos) Fig. 2), of four different kinds of woodpeckers (Picidae), of the Spotted Flycatcher (Muscicapra striata), the Common Dormouse (Muscardinus avellanarius), the Frog (Rana temporaria), the Toad (Bufo vulgaris), the Slow-worm (Anguis fragilis), the Common Newt (Triturus vulgaris), and many, many more. As irregular guests I have noted the Woodcock (Scolopax rusticola), the Hoopoe (Upupa epops), a species of Kite and two different ones of falcons, and the common Quail
(Coturnix coturnix); more often the Red Fox (Vulpes vulpes), squirrels (Sciuridae), roe deer (Caprellus sp.), the Buzzard (Buteo buteo), the Hare (Lepus europaeus), the Marten (Martes martes), and a lot of butterflies and bumble-bees - all in the suburb of our provincial town of Burgdorf!

JEANETTE DÜR-LINDT Merianweg 28 CH-3400 Burgdorf Switzerland.

\title{
The St Sorny Nature Demonstration Reserve in Southern France
}

St Sorny is situated in the hills of north Ardèche, near the west bank of the Rhône, approximately $25 \mathrm{~km}$ south of Tournon. It is a small, long-preserved estate, very quiet and secluded, consisting of a complex of old buildings half farm and half hermitage, with a small disused chapel (Fig. 1) - all lying near a curve of a tributary river of the Rhône. It is surrounded by unspoiled hills and its tranquil atmosphere invites peaceful meditation as well as research and demonstration.

The estate - of some 20 hectares - is largely of rather open and low forest of variable composition but in places dominated by coniferous or Sweet Chestnut (Castanea vulgaris) trees, with entry of many southern maquis plants. It was acquired in 1965 by three like-minded friends: Didier Roux, of a Geneva family, who has devoted his life to education and social work; Bernard Sartorius, from an old Basle family, who is a psychologist but widely concerned with environmental preservation; and Alfred Necker, doctor of laws and notary in Geneva, who has also devoted much of his spare time to conservation and forestry. The three friends together created a small French holding company: the Société Civile de Saint-Sorny.

Now, 26 years later, the above-mentioned three friends ardently wish that their efforts to preserve St Sorny be perpetuated, and are concerned about its future. They remain committed to their task of maintaining the entire estate of St Sorny, but in the past few years have transferred its management to an association, 'Friends of St Sorny' (ASSY), of which the Chairman, a schoolmaster from Geneva, and his wife and young family, are among its most frequent visitors-and-more, being indeed part-time residents. Although the three friends are still the owners of the estate and remain in control, they are not generally involved in the details of management; they do, however, assist in taking major decisions concerning the use and management of the estate.

There has been some question of transferring the title of the estate to ASSY. After serious reflection, however, the owners realize that they do not wish to transfer the title to the orgainzation of beneficiaries of the place, because they fear that members of the organization might, at some future time, change the purposes and use of St Sorny. So their intention now is to transfer the title of ownership of the Société Civile de Saint-Sorny to an impersonal and immortal, permanent Trustee, which would assure the continuance of the founders' original aims: conservation and appropriate use of the estate for peaceful purposes, including research and Nature demonstration. The beneficiary in coming years would be the ASSY; but should it disappear, or its members chart a new course for, or misuse of, St Sorny, the Trustee would have the right and duty to seek other beneficiaries who would adhere to the aims of the founders.

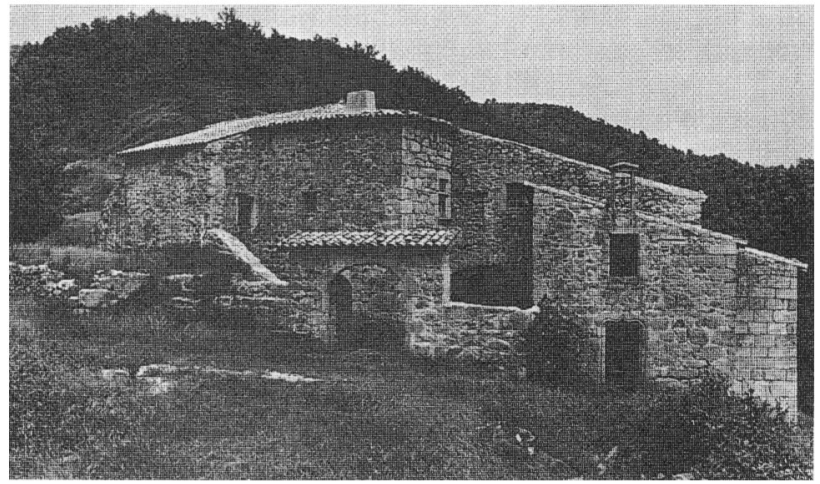

FIG. 1. The main buildings of St Sorny, with the entrance to the disused chapel on the right. The roofs are everywhere sound and professionally supervised at least twice-yearly, and there is rubbermattress sleeping provision on wooden floors for about 30 boyscouts, girlguides, or schoolchildren.

At present, without any advertisement or ad hoc organization, the buildings of St Sorny are occupied during about 130 nights of each year, especially by young people and their supervisors, the total occupancy being well over 1,000 individual nights yearly. It is confidently to be expected that, through due liaison with appropriate international bodies especially in France, Switzerland, and England, the former figure could easily be extended and the latter one multiplied without harm to the Reserve.

In addition to the Trustee, there would be need of 'Protectors', who would consult with the Trustee and keep it informed. The first protectors would be the three founders and former owners, and, after them, either representative(s) of their choosing or else their legal heir(s). They should receive an annual report from the Beneficiaries, with three copies to the Trustee. At least two of the Protectors should visit the Reserve in each year, whenever possible collaborating with the Beneficiaries in preparing their report to the Trustee.

It is thought that, if the above circumstances can be established and the present friendly relations maintained with the local populace, St Sorny has every chance of becoming a model of the kind of small Nature demonstration reserve that will be needed world-wide if modern Humankind is to continue in equable occupation of The Biosphere.

\section{ALFRED NECKER \\ 5 Rue Toepffer \\ I206 Geneva \\ Switzerland}

$\&$

NichOLAS POLUNIN. 